\title{
Taming the Wild North? High Seas Fisheries in the Warming Arctic
}

\author{
Rosemary Rayfuse
}

David Freestone once called the oceans 'the Cinderella of the climate negotiations; no one had asked them to the Ball'. And he should know. Perhaps no other international lawyer today possesses such a comprehensive and abiding knowledge of both the law of the sea and the international climate regime, gained from years of professional involvement in both spheres. It is thus fitting that this chapter should address the one frontier where these two subject areas, oceans and climate change, are most intertwined: the Arctic. In particular, the notion of the Arctic as a frontier will be used as a prism through which to evaluate the processes at play in relation to fisheries in the high Arctic.

The story of the climate/oceans interface in the Arctic is a complex, and continually emerging one, complicated by contested sovereignties, sovereign rights, and interests. While the history of human habitation in the Arctic stretches back more than twelve thousand years, ${ }^{2}$ thanks largely to its perennial ice cover, the waters of the central Arctic Ocean have remained inaccessible to all but the most intrepid scientists and adventurers and, in recent years, the nuclear-powered submarines of a few States. At least since the 1980s, however, international interest in the Arctic has been growing, fuelled by the prospects of a warming and climate-changed Arctic delivering up its potentially vast and, as yet, untapped natural resources. Even before Russia planted its now infamous flag on the seabed at the North Pole, ${ }^{3}$ other States were contemplating

1 Portions of this chapter are drawn from R Rayfuse, 'Regulating Fisheries in the Central Arctic Ocean: Much Ado about Nothing?' in N Vestergaard, BA Kaiser, L Fernandez and JN Larsen (eds), Arctic Marine Resource Governance and Development (Springer, 2018) 35-51 and R Rayfuse, 'The Role of Law in the Regulation of Fishing Activities in the Central Arctic Ocean' (2019) Marine Policy https:/doi.org/10.1016/j.marpol.2019.103562.

2 R Vaughan, The Arctic: A History (Sutton Publishing Limited, 1994).

3 A Bloomfield, 'Russia Claims North Pole with Arctic Flag Stunt' The Telegraph (1 August 2007), http://www.telegraph.co.uk/news/worldnews/1559165/Russia-claims-North-Polewith-Arctic-flag-stunt.html (all URLs accessed 6 October 2020 unless otherwise noted); R 
the opening of new shipping routes and salivating over the prospect of a new resource bonanza. ${ }^{4}$

While the Arctic represents one of the last great regulatory frontiers on earth, this expanding opportunism has not been occurring in a complete legal vacuum. Much of the Arctic consists of the land territory of the eight Arctic States, ${ }^{5}$ to which the full gamut of national and international law applies. In the oceans context, the international law of the sea is clear in its ascription of jurisdiction over ocean and seabed areas and in its articulation of the interests, rights and duties of all States in those areas. Within the territorial sea and exclusive economic zone, as well as on the continental shelf, it is the coastal State that has jurisdiction over the resources and powers with respect to pollution prevention and environmental protection. As far as the Arctic Ocean is concerned, many of the governance issues thus fall under the jurisdiction of the five Arctic Ocean coastal States - Canada, Denmark in respect of Greenland, Norway, Russia and the United States (the Arctic 5). As the Arctic has warmed and the ice has receded northwards their regulatory and governance efforts have similarly turned northwards, aimed at addressing the emerging challenges in this new frontier. Fuelling many of these efforts has been the work of the Arctic Council and its working groups, which have provided assessments of the state of the Arctic marine environment and contributed to the understanding of human uses in and threats to the Arctic as well as the consideration of possible law and policy responses to matters of common concern. ${ }^{6}$ Many of these responses have been adopted both individually and collectively by the Arctic States. Individually, they have developed their legal frameworks applicable to maritime activities, including offshore petroleum development in the marine Arctic. Collectively, and together with other members of the Arctic Council, they have adopted agreements on search and rescue ${ }^{7}$ and on

Rayfuse, 'Russian Flag at the North Pole' in J Hohmann and D Joyce (eds), International Law's Objects (Oxford University Press, 2018) 400-418.

4 For contemporaneous accounts see, e.g., D Cressey, 'Russia at Forefront of Arctic Land-grab' (2007) 448 Nature 520-521, https://doi.org/10.1038/44852ob; P Reynolds, 'Russia Ahead in Arctic “Gold Rush" ' BBC News (1 August 2007), http://news.bbc.co.uk/2/hi/in_depth/6925853. stm. See also R Sale and E Potapov, The Scramble for the Arctic: Ownership, Exploitation and Conflict in the Far North (Francis Lincoln, 2010).

5 Canada, Denmark (in respect of Greenland), Finland, Iceland, Norway, Russia, Sweden and the United States.

6 For information on the work of the Arctic Council see, http://www.arctic-council.org.

7 Agreement on Cooperation on Aeronautical and Maritime Search and Rescue in the Arctic, adopted 12 May 2011, (2O11) 5O ILM 1119. 
oil spill emergency preparedness and response, ${ }^{8}$ although admittedly much still remains to be done to resolve other frontier matters such as a common framework for Arctic oil and gas exploitation, or common rules on Arctic militarization, and related security issues.

Governance of two important emerging activities in the Arctic - shipping and fishing - lies, however, at least partially, beyond the jurisdiction of the Arctic States. On the high seas, beyond the exclusive economic zones and continental shelves of the coastal States, all States enjoy the traditional 'freedom of the high seas', which includes the freedoms of navigation and fishing. The corollary of this freedom is the principle of flag State jurisdiction, pursuant to which jurisdiction over vessels operating on the high seas can only be exercised by the flag State. In jurisdictional terms, the exercise of these freedoms implies that governance of navigation and high seas fishing activities must occur at the international level. With respect to navigation, the freedom (which can also be exercised within the exclusive economic zone) must be exercised on the basis of internationally agreed standards adopted under the auspices of the International Maritime Organization. With respect to fishing, the freedom can only be circumscribed by international agreement.

In recent years, the potential future exercise of these freedoms in the Arctic Ocean has been a matter of increasing international concern, fuelled by fears of environmental disaster and over-exploitation. In 2014, issues relating to Arctic shipping were largely dealt with through the adoption of the Polar Code, ${ }^{9}$ which sets out regulations relating to navigation and ship design for shipping in the polar regions, both in areas under and in areas beyond national jurisdiction. Moving ever northwards, the critical issue that was left to be resolved was how to plug the regulatory hole relating to the regulation of the conservation and management of any potential future fisheries in the high seas 'donut hole' in the central Arctic Ocean (referred to here as the Central Arctic Ocean). ${ }^{10}$

8 Agreement on Cooperation on Marine Oil Pollution Preparedness and Response in the Arctic, adopted 15 May 2013, СтS 2013/6.

9 See The International Code for Ships Operating in Polar Waters, available at http:// www.imo.org/en/MediaCentre/HotTopics/polar/Documents/POLAR\%2OCODE\%2O TEXT\%2OAS\%2OADOPTED.pdf.

10 According to Molenaar, the 'central Arctic Ocean' consists of both high seas areas and adjacent areas. See, EJ Molenaar, 'The December 2015 Washington Meeting on High Seas Fishing in the Central Arctic Ocean' [Web blog comment], 5 February 2016, available at http://dspace.library.uu.nl/handle/1874/363521 As a geographical matter this interpretation makes perfect sense. However, as a legal matter it is critically important to distinguish between areas under and areas beyond national jurisdiction. Thus, for present purposes, the terminology of 'Central Arctic Ocean' is used here to refer to the area of high seas covering approximately 2.8 million square kilometres which lies in the centre of the 
This chapter tells the story of the emerging governance framework for the conservation and management of fisheries in the earth's most northerly waters the Central Arctic Ocean. Tracing legal developments in this last great frontier, the chapter seeks to shed light on how these farthest reaches of the wild north are being tamed. Applying the frontier analogy at the centre of this volume to the high seas fisheries context, the chapter begins with a brief description of the new frontier and the basic legal framework applicable there. It then turns to an examination of the manner in which the Arctic 5 have staked their claim as the drivers of legal developments in the Central Arctic Ocean. In doing so it is hoped to reveal something about both the influence of the law of the sea on the Arctic and the influence of the new, formerly peripheral, frontier of the Central Arctic Ocean on the law of the sea itself.

\section{Into the Unknown: the Fish Resources of the Central Arctic Ocean}

There is no doubt that the Arctic region as a whole contains some very significant fish stocks. ${ }^{11}$ However, very little is known about the fishery resources of the Central Arctic Ocean. ${ }^{12}$ Whether this is because the polar ice cap has thus far made fishing impossible, or because there are simply no fish there, has long been a matter of conjecture. ${ }^{13}$ In recent years, however, increasing ocean temperatures coupled with decreasing sea ice coverage caused by climate change have been linked with the northward expansion of sub-arctic and temperate

Arctic Ocean both beyond and completely surrounded by the exclusive economic zones of the Arctic 5. In other words, the discussion here relates only to the high seas and only to the high seas fishing in the Central Arctic Ocean, and not in the other 'Arctic' high seas areas such as the 'Banana Hole' in the North East Atlantic, the Barents Sea 'Loophole', or the 'Donut Hole' in the Central Bering Sea.

11 J Eamer, GM Donaldson, AJ Gaston et al., Life Linked to the Ice: A Guide to Sea-ice-associated Biodiversity in This Time of Rapid Change, CAFF Assessment Series No 10 (Conservation of Antarctic Flora and Fauna, Iceland, 2013).

12 BA Bluhm, KN Kosobokova and EC Carmack, 'A Tale of Two Basins: An Integrated Physical and Biological Perspective of the Deep Arctic Ocean' (2015) 139 Progress in Oceanography 89-121.

13 GE Shephard, K Dalin, R Peldszus et al., 'Assessing the Added Value of the Recent Declaration on Unregulated Fishing for Sustainable Governance of the Central Arctic Ocean' (2016) 66 Marine Policy 50-57, 55; Final Report of the Third Meeting of Scientific Experts on the Fish Stocks of in the Central Arctic Ocean (Washington DC, 14-16 April 2015), https://www.afsc.noaa.gov/Arctic_fish_stocks_third_meeting/meeting_reports/3rd_ Arctic_Fish_Final_Report_10_July_2015_final.pdf. 
fish species, ${ }^{14}$ and six stocks have been identified as having a 'high potential' to expand into the Central Arctic Ocean. ${ }^{15}$ Of particular interest is the polar cod (Boreogadus saida), the most abundant Arctic fish, first and second year juveniles of which are already known to be found under the pack ice in the Eurasian basin. ${ }^{16}$ Admittedly, nearly all such northward migration or expansion is expected to occur within the exclusive economic zones of the Arctic 5 and scientists remain sceptical of any further northwards expansion into the Central Arctic Ocean in the short term. ${ }^{17}$ Nevertheless, approximately 40 percent of the Central Arctic Ocean, primarily in the Beaufort, Chuchki and East Siberian Seas north of Canada, Russia and the United States, is now ice free in summer, ${ }^{18}$ and warming trends are set to continue. The possibility therefore clearly exists for the eventual migration of fish into the Central Arctic Ocean. In addition, extensive fishing industries already operate in some Arctic and sub-Arctic regions, in particular off Norway and Russia. The potential therefore also exists for fishing vessels to move into a newly ice-free Central Arctic Ocean to explore for and, if found, commercially exploit those fishery resources.

Unfortunately, the history of commercial exploitation of fish stocks is replete with instances of over-exploitation and stock collapse. ${ }^{19}$ Particularly

14 P Wassmann, CM Duarte, S Agusti et al., 'Footprints of Climate Change in the Arctic Marine Ecosystem' (2011) 17 Global Change Biology 1235-1249; JS Christensen, CW Mecklenburg, OV Karamishko et al., 'Arctic Marine Fishes and the Fisheries in Light of Global Climate Change' (2014) 2o Global Change Biology 352-359.

15 A Hollowed, B Planque and H Leong, 'Potential Movement of Commercial Fish and Shellfish Stocks from the Sub-Arctic to the Arctic Ocean' (2013) 22 Fisheries Oceanography 355-370.

16 C David, B Lange, T Krumpen et al., 'Under-ice Distribution of Polar Cod Boreogadas saida in the Central Arctic Ocean and Their Association with Sea-ice Habitat Properties' (2016) 39 Polar Biology 981-994.

17 Final Report, above (n 13).

18 Estimates point to ice free summer conditions by 2050. See JE Overland and M Wang, 'When Will the Summer Arctic Be Nearly Ice Free?' (2013) 40 (10) Geophysical Research Letters 2097-2101; JA Screen and C Deser, 'Pacific Ocean Variability Influences the Time of Emergence of a Seasonally Ice-Free Arctic Ocean' (2019) Geophysical Research Letters, DOI: 10.1029/2018G L081393; D Notz and J Stroeve, 'The Trajectory towards a Seasonally Ice-free Arctic Ocean' (2018) 4(4) Current Climate Change Reports 407-416, https://doi. org/10.1007/s40641-018-0113-2.

19 A classic, but by no means the only, example is the rapid expansion of the pollock fishery in the high seas of the Central Bering Sea in the 1980s. Within less than a decade, the catch taken rose from 18,00o $\mathrm{mt}$ in 1980 to a high of 1,448,ooo $\mathrm{mt}$ in 1989. In 1992 the stock crashed yielding only 10,00o mt of pollock. To this day, stocks have not recovered sufficiently to allow the moratorium put in place in 1993 to be lifted, and the fishery is effectively functus. R Rayfuse, 'Regulating Fisheries in the Central Arctic Ocean: Much Ado About Nothing?' in N Vestergaard, BA Kaiser, L Fernandez and J Nymand Larsen 
in situations where little is known about a species or a particular fish stock, unregulated expansion into new fisheries may effectively wipe out a species or stock before its existence is even formally recognized or understood. ${ }^{20}$ It is precisely because of the lack of scientific data and uncertainty surrounding the existence and/or potential migration of fish stocks into the Central Arctic Ocean, and the effect of any fishery on what is thought to be the extremely fragile marine ecosystem of the Central Arctic Ocean, that scientists and others started calling for a ban on the commencement of any commercial fishing in the Central Arctic Ocean pending the establishment of scientifically sound baselines and management measures. ${ }^{21}$

\section{3 The Ground Rules: the International Legal Framework for High Seas Fisheries}

The basic legal framework governing high seas fisheries is set out in the Law of the Sea Convention (LOSC) ${ }^{22}$ and the UN Fish Stocks Agreement

(eds), Arctic Marine Resource Governance and Development (Springer, 2018) 35-51, 39. See also L Zou and HP Huntington, 'Implications of the Convention on the Conservation and Management of Pollock Resources in the Central Bering Sea for the Management of Fisheries in the Central Arctic Ocean' (2018) 88 Marine Policy 132-138.

20 JF Caddy and RC Griffiths, Living Marine Resources and Their Sustainable Development: Some Environmental and Institutional Perspectives, FAO Fisheries Technical Paper No 353 (FAO, 1995).

21 See, e.g., R Rayfuse, 'Melting Moments: The Future of Polar Oceans Governance in a Warming World' (2007) 16(2) Review of European Community and International Environmental Law 196-217. In 2012, an open letter from 2000 scientists from 67 countries identified the need for biological information to understand the presence, abundance, structure, movements and health of fish stocks and the role they play in the broader ecosystem of the Central Arctic Ocean in order to enable the adoption of a robust management system and to better understand the effects of fishing removals on other components of that ecosystem. See, PEW Open Letter from International Scientists, available at https://www.pewtrusts.org/ /media/legacy/oceans_north_legacy/page_attachments/ international-arctic-scientist-letter-with-sigs-522012.pdf?la=en; B Baker, 'Scientists Move to Protect Central Arctic Fisheries' (2012) 62(9) BioScience 852. In 2014, Inuit leaders called for a moratorium on fishing in the Central Arctic Ocean until fish stocks have been adequately assessed and a sustainable management regime — which involves the Inuitis in place. See the Kitigaaryuit Declaration, adopted 24 July2014, Inuit Circumpolar Council, https://iccalaska.org/wp-icc/wp-content/uploads/2016/o1/2014-KitigaarguitDeclaration-Final-Signed.pdf.

Adopted 10 December 1982, in force 16 November 1994, 1833 UNTS 3. 
(FSA). ${ }^{23}$ Articles 116-119 of the LOSC provide that all States have the right for their nationals to fish on the high seas, albeit subject to the duties to conserve and to cooperate with other States in the conservation and management of the resources and to the rights, duties and interests of coastal States. The duty to conserve requires States to adopt appropriate conservation and management measures, based on the best scientific evidence available, both individually and in cooperation with other States whose nationals exploit similar resources or different resources in the same area. The duty to cooperate requires the establishment of subregional or regional fisheries management organizations (RFMOs) although it is also recognized that there may be some cases where a formal organizational structure is unnecessary, and the objectives of conservation and management can be met through an 'arrangement' (RFMA).

The FSA elaborates on the general requirements of the LOSC. Importantly, it requires the application of both precautionary and ecosystem-based approaches to conservation and management. ${ }^{24}$ In addition, it further institutionalizes the duty to cooperate by requiring its exercise through RFMO/As and by requiring States fishing for straddling or highly migratory stocks on the high seas either to 'agree to play by the rules' 25 adopted by these arrangements or to refrain from fishing. Interestingly, where no such arrangement exists, the FSA requires the good faith negotiation of these cooperative arrangements - which are to be open to all States having a 'real interest' in the fisheries concerned - particularly where evidence exists that fish stocks may be under threat of over-exploitation or where a new fishery is being developed. ${ }^{26}$ The Arctic 5 are thus under a positive obligation to cooperate both amongst themselves and with other States who have 'real interests' in the conservation and management of the fish stocks of the Central Arctic Ocean.

231995 Agreement for the Implementation of the Provisions of the UN Convention on the Law of the Sea of 10 December 1982 relating to the Conservation and Management of Straddling Fish Stocks and Highly Migratory Fish Stocks (FSA), 2167 UNTS 3.

24 See, FSA, ibid Arts 5, 6 and Annex II.

25 D Balton, 'Strengthening the Law of the Sea: The New Agreement on Straddling Stocks and Highly Migratory Fish Stocks' (1996) 27 Ocean Development and International Law 121-151, 138. See FSA, above (n 23), Art 8(4).

26 Ibid Art 8. 
International discussions on the future management of Central Arctic Ocean fisheries have their origins in a joint resolution passed by the United States Senate in 2007 'directing the United States to initiate international discussions and take necessary steps with other Nations to negotiate an agreement for managing migratory and transboundary fish stocks in the Arctic Ocean'. ${ }^{27}$ In 2008, with increasing European interest in the Arctic, the European Union proposed the expansion of the North-East Atlantic Fisheries Commission (NEAFC), whose geographical scope of application includes a small wedge totalling approximately eight percent of the Central Arctic Ocean, to cover the entire Central Arctic Ocean. ${ }^{28}$ This was, however, rejected by Canada and the United States as they are not members of NEAFC. ${ }^{29}$ Amid increasingly fervent calls for action, commentators suggested a whole host of possible governance structures to address fisheries, either in isolation or as part of a broader marine environmental approach. The more conservative suggestions included the establishment of a new regional fisheries management organization, ${ }^{30}$ or a more broadly mandated regional oceans management organization, ${ }^{31}$ or the adoption of an Arctic Ocean framework convention applicable to areas both

27 US Senate Joint Resolution No 17 of 2007, Senate 4 October 2007, House of Representatives May 20o8, President Bush signature 4 June 2008. Public law 110-243, 122 STAT. 1569-1571 (3 June 2008).

28 Сом (2008) 763 of 23 November 2008, 'Communication from the Commission to the European Parliament and the Council on The European Union and the Arctic Region', 8. In short, the only existing RFMo/A relevant to the Central Arctic Ocean that enjoys any sort of international participation is the North-East Atlantic Fisheries Commission (NEAFC), whose parties are limited to Denmark (in respect of the Faroe Islands and Greenland), the European Union, Iceland, Norway and Russia. As a matter of basic treaty law, NEAFC regulations do not apply to any non-member States. Moreover, the sector of the NEAFC convention area which lies in the Central Arctic Ocean represents only 8 percent of the total area of the Central Arctic Ocean.

29 EJ Molenaar, 'Arctic Fisheries Conservation and Management: Initial Steps of Reform of the International Legal Framework' (2009) 1 Yearbook of Polar Law 427-463, 456-458.

30 See, for example, R Huebert and BB Yeager, A New Sea: The Need for a Regional Agreement on Management of the Arctic Marine Environment (wwF International Arctic Programme, 2008)33,http://wwf.panda.org/?12226o/A-New-Sea-The-Need-for-a-Regional-Agreementon-Management-and-Conservation-of-the-Arctic-Marine-Environment.

31 R Rayfuse, 'Protecting Marine Biodiversity in Polar Areas Beyond National Jurisdiction' (2009) 17(1) Review of European Community and International Environmental Law 3, 11; R Rayfuse, 'Melting Moments', above (n 21). 
under and beyond national jurisdiction. ${ }^{32}$ More controversial suggestions included simply dividing the Central Arctic Ocean between the Arctic $5{ }^{33}$ or adopting a complete freeze on jurisdictional claims to the central Arctic basin, reminiscent of the freeze on Antarctic sovereignty claims adopted in the Antarctic Treaty. ${ }^{34}$

Given the near fever pitch of interest in the Arctic, it was perhaps hardly surprising that, in 2008, the Arctic 5 adopted the Ilulissat Declaration in which they asserted their special role as 'stewards' of the Arctic, noting that 'by virtue of their sovereignty, sovereign rights and jurisdiction in large areas of the Arctic Ocean' they were in 'a unique position to address [the] possibilities and challenges' posed by a warming Arctic. They reminded the international community that there 'already exists an extensive international legal framework [that] applies to the Arctic Ocean' and that there was thus 'no need to develop a new comprehensive international legal regime to govern the Arctic Ocean'. They committed, rather, to 'continue to cooperate with each other and with other interested parties' to 'keep abreast of developments' and to 'continue to implement appropriate measures' where necessary. 35

While the Arctic 5 recognized that the legal framework applicable to the Arctic might be extensive, they also acknowledged that it was not exhaustive. Although not mentioned in the Ilulissat Declaration, one area in particular that the Arctic 5 recognized as requiring action was the emerging need for an effective regional fisheries conservation and management regime applicable to the Central Arctic Ocean.

In 2009, the United States raised the possibility of convening an intergovernmental meeting aimed at adopting a non-legally binding instrument on Arctic fisheries during a side event at the meeting of the FAO Committee of Fisheries, and the question of the regulation of Arctic Ocean fisheries was broached during negotiations on the UNGA annual resolutions on Oceans and 'Sustainable Fisheries' during 2008 and 2009. ${ }^{36}$ No tangible outcomes were

$32 \mathrm{~T}$ Koivurova and EJ Molenaar, International Governance and Regulation of the Marine Arctic: A Proposal for a Legally Binding Instrument (wwF, 2010), http://assets.panda.org/ downloads/3inı_final.pdf.

33 DM Johnston, 'The Future Arctic Ocean: Competing Domains in International Public Policy' (2003) 17 Ocean Yearbook 596, 616.

34 OR Young, 'Whither the Arctic? Conflict or Cooperation in the Circumpolar North' (2009) 45(232) Polar Record 73, 79.

35 Ilulissat Declaration, adopted 28 May 2008, (2009) 48 ILM 362.

$36 \quad$ S Ryder, 'The Declaration Concerning the Prevention of Unregulated High Seas Fishing in the Central Arctic Ocean' (15 July 2015), http://ablawg.ca/2015/07/31/the-declarationconcerning-the-prevention-of-unregulated-high-seas-fishing-in-the-central-arcticocean/. 
produced from these discussions due to objections by at least some of the Arctic 5 to what was perceived as external meddling in their area of special interest. Nevertheless, these discussions did serve to consolidate the conviction, expressed in the Chair's Summary of the second Arctic Ocean Foreign Minister's Meeting which took place in 2010, that the Arctic 5 'have a unique interest and role to play in current and future efforts for the conservation and management of fish stocks' in the Arctic Ocean, and that the development of any new international instrument on Arctic Ocean fisheries should be both initiated and led by them outside the framework of any other existing mechanisms - including the Arctic Council. ${ }^{37}$

Continuing to stake their stewardship claim, between June 2010 and July 2015 the Arctic 5 convened a number of policy and science meetings to discuss Arctic Ocean fisheries, with the policy meetings setting the terms of reference for, and reviewing the outcomes of, the science meetings. The first policy meeting in 2010 acknowledged that the current state of information did not allow for a full understanding of the status of fish stocks and the impact of climate change on such stocks in the Arctic Ocean. Although commencement of commercial fishing in the Central Arctic Ocean was not considered imminent, the need for further scientific research on the state and nature of fish stocks and their ecosystems was clear. A process was thus established whereby scientific experts would meet to evaluate current information and identify future research requirements and priorities. ${ }^{38}$ The first scientific meeting, held in 2011 and attended by scientists from the Arctic 5 , noted the limited knowledge and lack of urgency as well as the need for baseline data. ${ }^{39}$

Although initially concerned with Arctic Ocean fisheries in general, by 2013 attention was focused more narrowly on the prospects for commercial fisheries in the Central Arctic Ocean. The second scientific meeting, held in 2013 and attended by scientists from the Arctic 5 and representatives of a number of international scientific organizations and the Inuit Circumpolar Conference, reported that there were no near-future-prospects for commercial concentrations of fish in the Central Arctic Ocean but that much more research was

37 The Ministry of Foreign Affairs of the Russian Federation, Chair's Summary of the Second Arctic Ocean Foreign Ministers Meeting (Chelsea, Canada, 29 March 2010), http://www. mid.ru/en/foreign_policy/news/-/asset_publisher/cKNonkJEo2Bw/content/id/257162.

38 For discussion, see $\mathrm{N}$ Wegge, 'The Emerging Politics of the Arctic Ocean: Future Management of the Living Marine Resources' (2015) 51 Marine Policy 331-338.

39 Report of a Meeting of Scientific Experts on Fish Stocks in the Arctic Ocean, Anchorage, Alaska, 15-17 June 2011. 
needed. ${ }^{40}$ The scientists were tasked with developing an inventory of research and monitoring programs and preparing a report on the status and gaps in knowledge on the distribution and abundance of fishing in the Central Arctic Ocean as well as a Joint Program of Scientific Research and Monitoring for the Central Arctic Ocean ${ }^{41}$ Both of these items were delivered at the third scientific meeting in 2015 which was attended by representatives from scientific institutions in the Arctic 5 as well as from other States conducting Arctic research (China, Japan, Korea, Iceland) and members of a number of international Arctic research organizations including the International Arctic Science Committee, the Sustained Arctic Observing Network, the International Council for the Exploration of the Sea (ICES), the North Pacific Marine Science Organization (PICES), and the Ecosystem Approach Expert Group of the Protection of the Arctic Marine Environment Working Group of the Arctic Council. By this third meeting, it was clear that, while any fishing was unlikely to occur in the near future, the state of currently available scientific information needed to be radically improved in order to reduce the substantial uncertainties associated with Arctic fish stocks and enable the adoption of a robust management system, if, and when, it should become necessary. Also needed would be interim measures to deter any unregulated fishing in the Central Arctic Ocean in the future and ensure that non-commercial fishing did not undermine the purpose of those interim measures. This would require coordinated monitoring, control and surveillance activities aimed at ensuring compliance. ${ }^{42}$

These policy and science meetings culminated in the adoption, on 16 July 2015, of the Oslo Declaration Concerning the Prevention of Unregulated High Seas Fishing in the Central Arctic Ocean ${ }^{43}$ in which the Arctic 5 agreed voluntarily to refrain from commercial fishing in the CAO unless and until appropriate science-based management measures are in place. Like the Ilulissat Declaration before it, the Oslo Declaration caused consternation among other States - including their Arctic neighbours - who were worried that their own rights and interests in the Arctic, including in access to and long-term

40 Report of the Second Scientific Meeting on Arctic Fish Stocks, Tromsø, Norway, 28-31 October 2013 .

41 Chairman's Statement, Meeting on Arctic Fisheries, Nuuk, Greenland, 24-26 February 2014, https://naalakkersuisut.gl/en/Naalakkersuisut/News/2014/o2/Arktisk-hoejsoefiskeri.

42 Final Report of the Third Meeting of Scientific Experts on Fish Stocks in the Central Arctic Ocean, Washington DC, 14-16 April 2015, https://www.afsc.noaa.gov/Arctic_fish_stocks_ third_meeting/default.htm.

43 Declaration Concerning the Prevention of Unregulated High Seas Fishing in the Central Arctic Ocean (Oslo Declaration), adopted 16 July 2015, https://www.wto.org/english/tratop_e/rulesneg_e/fish_e/2015_oslo_declaration.pdf. 
conservation and sustainable management of Arctic fishery resources were being ignored. ${ }^{44}$ Iceland, in particular, objected to having been excluded from the discussions, apparently on the basis that fish species occurring within its exclusive economic zone also occur in the Arctic Ocean making it also an Arctic Ocean coastal State. ${ }^{45}$

While the Oslo Declaration was criticized by some as constituting a form of Arctic 5 exceptionalism, ${ }^{46}$ it was hailed by others as a precedent setting, precautionary approach to the management of fish stocks in the Central Arctic Ocean. ${ }^{47}$ In truth, as a legal matter, the non-binding Oslo Declaration did very little to fill the regulatory gap relating to high seas fishing in the Central Arctic Ocean. ${ }^{48}$ Only applicable, to the Arctic 5 , the Declaration did not, in fact, prohibit any commercial fishing. Rather, it simply suggested that any such future fishing would need to be subject to measures adopted by either existing or future regional fisheries arrangements. At best, all the Declaration did was prevent unregulated fishing by any of the Arctic 5 , none of whom were engaged in the practice in any event. ${ }^{49}$ What it did do, however, was 'acknowledge the interests of other States in preventing unregulated high seas fisheries in the central Arctic Ocean' and suggest the commencement of a 'broader process', open to all interested States, aimed at developing measures consistent with its terms. ${ }^{50}$ Having clearly staked their claim, the Arctic 5 thus sought to entice others to promote its maintenance. Agreement

The 'broader process' envisaged in the Oslo Declaration commenced in Washington, DC in December 2015 when the United States initiated, hosted and chaired a meeting of the Arctic 5 along with delegations from China, the European Union (EU), Iceland, Japan and South Korea (colloquially referred to as the Arctic 5+5). Six subsequent negotiating sessions took place, informed

\footnotetext{
44 Wegge, above (n 38), 335 .

45 E Quinn, 'Iceland Blasts Arctic Five for Exclusion from Fishing Agreement' Eye on the Arctic (30 July 2015), http://www.rcinet.ca/eye-on-the-arctic/2015/07/3o/iceland-blastsarctic-five-for-exclusion-from-fishing-agreement/.

46 Wegge, above (n 38$)$, 337.

47 Shephard et al., above (n 13), 55 .

48 Rayfuse, 'Regulating Fisheries in the Central Arctic Ocean', above (n 1), 35-51.

49 Ryder, above (n 36$)$.

5o Oslo Declaration, above (n 43$)$, final paragraph.
} 
by the reports of the parallel fourth and fifth meetings of scientific experts on fish stocks in the Central Arctic Ocean which were attended by participants representing the 10 governments of the Arctic 5+5, as well as interested organizations such as the Arctic Council, PICES and ICES. ${ }^{51}$

From the outset, the working assumption of the process, based on the scientific advice received, was that 'it is unlikely that there will be a stock or stocks in the high seas area of the central Arctic Ocean sufficient to support a sustainable commercial fishery in that area in the near future. ${ }^{2}$ It was, however, obvious that this assumption equally implied a belief that such fishing would eventually occur in the future, a belief which, when coupled with the rapid climate-related changes occurring in the Arctic region, provided a certain impetus to the negotiations.

The negotiations were based on the recognition by all participants of two critical needs: the need for a precautionary approach to the conservation and sustainable use of the living marine resources of the Central Arctic Ocean and to safeguarding the marine ecosystem, and the need to improve scientific understanding of both the future fisheries potential and the broader ecosystem of the Central Arctic Ocean. ${ }^{53}$ Critical issues to be resolved included the form the negotiated outcome would take, the content of any interim measures to be adopted, the regulation of exploratory fishing, decision making and the mechanism by which decisions would be made to move to the adoption of a more permanent regulatory framework.

In terms of the form of the envisaged agreement, three approaches were initially on the table: adjusting the Oslo Declaration to adopt a broader nonbinding statement; negotiating a binding international agreement that would, among other things, commit parties to essentially the same measures as those expressed in the Oslo Declaration; or establishing one or more regional

$5^{1} \quad$ Final Report of the Fourth Meeting of the Scientific Experts on Fish Stocks in the Central Arctic Ocean, Tromsø, Norway, 26-28 September 2016, https://www.afsc.noaa.gov/Arctic fish_stocks_fourth_meeting/; Final Report of the Fifth Meeting of the Scientific Experts on Fish Stocks in the Central Arctic Ocean, Ottawa, Canada, 24-26 October 2017, https://www. afsc.noaa.gov/Arctic_fish_stocks_fifth_meeting/default.htm.

52 Chairman's Statement on the First Meeting on High Seas Fisheries in the Central Arctic Ocean (Washington, DC, 1-3 December 2015), available at https://www.state.gov/remarksand-releases-bureau-of-oceans-and-international-environmental-and-scientific-affairs/ meeting-on-high-seas-fisheries-in-the-central-arctic-ocean/

53 Chairman's statement on the Fourth Meeting on High Seas Fisheries in the Central Arctic Ocean, Tórshavn, The Faroe Islands, 29 November — 1 December 2016, available at https://www.state.gov/remarks-and-releases-bureau-of-oceans-and-international -environmental-and-scientific-affairs/meeting-on-high-seas-fisheries-in-the-centralarctic-ocean-4/ 
fisheries management organizations or arrangements for the area. None of these approaches was considered to be mutually exclusive and it was accepted that they might be combined in a 'step-by-step or evolutionary fashion'. ${ }^{54}$ Negotiations revolved around a continually updated draft Chairman's text that eventually took the form of the draft legally-binding agreement, which, in 2017, became the Agreement to Prevent Unregulated High Seas Fisheries in the Central Arctic Ocean (CAOF Agreement). ${ }^{55}$ In the end, the process shied away from establishing a new RFMO/A, adopting, instead, the incremental approach whereby the resulting agreement represents a first step towards the possible establishment of a RFMO/A in the future.

With respect to the other issues, agreement was reached relatively easily on the content of interim measures to prevent unregulated commercial fishing in the Central Arctic Ocean, which effectively replicate those in the Oslo Declaration and provide for an indefinite abstention from commercial high seas fishing which can be lifted when certain substantive and procedural conditions are met. ${ }^{56}$ Agreement was also reached that exploratory fishing conducted for the purpose of assessing the sustainability or feasibility of future commercial fisheries should only be conducted pursuant to these interim measures and any future conservation and management measures to be adopted by the parties. ${ }^{57}$ It was also agreed that scientific research activities involving the catching of fish are not to be used to undermine the prevention of unregulated commercial or exploratory fishing, or the health of the marine ecosystem. ${ }^{58}$

Agreement was also reached relatively easily on the development of a Joint Program of Scientific Research and Monitoring (JPSRM) aimed at improving scientific understanding of both the future fisheries potential and the broader ecosystem of the Central Arctic Ocean. The stated objectives of the JPSRM are to increase knowledge of the living marine resources of the Central Arctic Ocean and the ecosystems in which they occur ${ }^{59}$ and, based on this knowledge,

54 Chairman's Statement (First Meeting), above (n 52); Chairman's Statement on the Third Meeting on High Seas Fisheries in the Central Arctic Ocean, (Iqualuit, Nunavut, Canada, 6-8 July 2016), https://www.state.gov/remarks-and-releases-bureau-of-oceans-andinternational-environmental-and-scientific-affairs/meeting-on-high-seas-fisheries-inthe-central-arctic-ocean-3/.

55 The Agreement was adopted in 2017, however, signature was delayed until 2018. Agreement to Prevent Unregulated High Seas Fisheries in the Central Arctic Ocean, 3 October 2018, not yet in force, oJ L 73/3 (15 March 2019).

$56 \quad$ Ibid Arts 3 and 5 .

57 Ibid Arts 3(3) and 5(1)(d).

58 Ibid Art 3(4).

59 Ibid Art 4. 
to determine whether fish stocks exist that might be commercially viable on a sustainable basis without negatively affecting this ecosystem. In other words, the Joint Program is to determine how the ecosystems in the Central Arctic Ocean are changing, thereby making possible future decisions as to when, how, and under what conditions, to launch commercial fisheries. Precisely how the JPSRM will be organized remains to be seen, ${ }^{60}$ although it is clearly intended that it will build on the work of the scientific meetings which helped inform the negotiations. ${ }^{61}$

Agreement was not, however, so easily achieved on the conditions under which a decision to commence negotiations for a formal RFMO/A might be taken. While some of the Arctic 5 sought to consolidate their 'special status' as Central Arctic Ocean coastal States and, essentially, to retain a defacto veto over the process, the other States $($ the +5$)$ were concerned to limit what they saw as creeping coastal State jurisdiction and the potential precedent setting effect of giving such power to the Arctic 5. Ultimately, a package deal was reached involving the inclusion of a special paragraph in the preamble which recognizes the special responsibilities and special interests of the Arctic 5 in relation to the conservation and management of the fish stocks of the central Arctic Ocean as a whole (not just the high seas area) and the requirement set out in Article 6 of the Agreement for consensus decision-making (taken as meaning 'the absence of any formal objection made at the time the decision was taken'). Also included was a sunset clause (Article 13) relating to the duration of the CAOF Agreement, which will have an initial duration of 16 years from the date of its entry into force. During that time, should the science indicate that some commercial fishing could be undertaken on a sustainable basis, any decision to authorize such fishing or to initiate negotiations on a broader management agreement will require a consensus of the parties to the Agreement. Without such a consensus, the status quo will prevail. The Agreement may be extended, unless any party objects, for successive five-year periods, however, should it lapse, there is no requirement to commence negotiations towards a broader management regime.

While not a formal veto, the requirement of consensus appears to enable any one of the parties to exercise a de facto veto over the commencement of negotiations towards a formal RFMO/A, at least for the duration of the

6o TI van Pelt, HP Huntington, OV Romanenko and FJ Mueter, 'The Missing Middle: Central Arctic Ocean Gaps in Fishery Research and Science Collaboration' (2017) 85 Marine Policy 79-86.

61 Final Report (Fourth Meeting), above (n 51); Final Report of the Fifth Meeting of Scientific Experts on Fish Stocks in the Central Arctic Ocean, Ottawa, Canada, 24-26 October 2017. 
Agreement. However, as Article 14 makes clear, the parties remain bound at all times by all their other obligations under international law, including those under the LOSC and the FSA with respect to cooperation and conservation. Indeed, whether or not the Agreement expires or is terminated, each party retains the right to propose commencement of negotiations on the establishment of one or more additional regional or subregional fisheries management organizations or arrangements for the Central Arctic Ocean at any time. In addition, parties also retain their rights and obligations arising from other agreements compatible with the CAOF Agreement. Importantly, Article 14(4) provides that nothing in the CAOF Agreement prejudices or undermines existing international fisheries management mechanisms. Thus, NEAFC remains entitled to adopt conservation and management measures of its choosing, applicable to its members, with respect to the small sector of the Central Arctic Ocean falling within its regulatory area. Similarly, Norway and Russia remain entitled to authorise commercial fishing by their vessels in the Central Arctic Ocean pursuant to the Joint Norwegian-Russian Fisheries Commission. ${ }^{62}$ In other words, at least some members of the Arctic 5 retain their ability to fish commercially in some or all of the Central Arctic Ocean if and when they choose to do so, regardless of the measures set out in the CAOF Agreement. Other parties to the Agreement similarly retain their ability to negotiate other arrangements for the Central Arctic Ocean, although clearly the expectation is that they will not - at least not until the science supports such a move. There thus remains the potential for conflict between the interests of at least some of the Arctic 5 and the other parties to the Agreement in this emerging frontier.

It is interesting to note that the Arctic 5 were clearly careful about who they invited to the negotiating table. Participation by Iceland, in its own right, and by Denmark, Finland and Sweden as part of the EU, ensured that all Arctic States were involved, thereby alleviating the concerns of their Arctic neighbours about Arctic 5 exceptionalism. Participation by China, Japan and Korea reflected their status as major global distant-water fishing States. Given the absence of any historical fishing activities in the Central Arctic Ocean, it is arguable that all States have an equal interest in the conservation and management of fish stocks there and that every State should therefore either have been invited to participate in the negotiations or at least be entitled as of right to become party to the CAOF Agreement and any subsequent RFMO/A. Article 10 of the Agreement, however, makes accession contingent on an invitation from the parties. While potentially concerning, in this respect the Agreement

62 Rayfuse, 'Regulating Fisheries in the Central Arctic Ocean', above (n 1), 44. 
reflects past State practice evidencing a clear trend towards limited participation. ${ }^{63}$ Nevertheless, the disadvantage of limited participation is that nonparties will not be bound by the Agreement. Article 8 thus requires the parties to encourage non-members to take measures consistent with the Agreement, even while not promising them a right to accede, and to take measures consistent with international law to deter activities of non-party vessels that undermine effective implementation of the Agreement. These obligations, too, are consistent with other international fisheries agreements. ${ }^{64}$

A Frontier Tamed?

In pursuing the adoption of the CAOF Agreement the Arctic 5 have played a 'long game'. With the adoption of the Ilulissat and Oslo Declarations they have occupied the legal territory, staking their claim to their interests in the area. In pursing the 'Broader Process' they have engaged with their duty to cooperate by bringing other States into an arrangement that both invokes the power of the existing law of the sea and consolidates the power of their assertion. While apparently self-serving, as a substantive matter the result is the first truly precautionary high seas fisheries agreement, adopted in advance of any fishing activity occurring and in the face of considerable uncertainty and extremely limited scientific knowledge regarding the existence of, and any potential for, high seas fisheries in the Central Arctic Ocean. The Agreement establishes a mechanism whereby necessary scientific knowledge can be acquired which can then be used to inform decisions about future conservation and management measures. While this may fall short of the complete ban or moratorium on Central Arctic Ocean commercial fishing that was hoped for by some, in theory at least, it represents an attempt to ensure that no commercial fishing will take place unless and until it can be done on a sustainable basis and in accordance with conservation and management measures established by the parties to the Agreement. Thus, while a manifestation of existing law of the sea, the Agreement also moves far beyond existing agreements.

63 EJ Molenaar, 'International Regulation of Central Arctic Ocean Fisheries' in MH Nordquist, JN Moore and R Long (eds), Challenges of the Changing Arctic (Brill/Nijhoff, 2016) 429-463.

64 R Rayfuse, 'Regional Fisheries Management Organizations' in DR Rothwell, AG Oude Elferink, K Scott and T Stephens (eds), The Oxford Handbook of the Law of the Sea (Oxford University Press, 2015) 439-462. 
However, the CAOF Agreement is only a first step towards the possible establishment of a future formal management arrangement. Clearly, the expectation is that by the end of the initial 16 -year period adequate scientific information will be available to allow the parties to make informed decisions about the state of the resources, the potential to initiate any commercial fishing on a sustainable basis, and whether there is a need for a new regional fisheries management organization. Of course, there are no guarantees that the Agreement will achieve its objectives. Nevertheless, by establishing the initial legal framework for environmentally sound decision making regarding the potential for future fisheries in a warming Central Arctic Ocean, the Agreement is an emanation of the interest of the Arctic 5 in driving the future regulation of any such fisheries. Although the Agreement is not yet in force, ${ }^{65}$ it represents, in this respect, both a significant frontier claim and a significant step in the taming, in legal terms, of the wild north of the Central Arctic Ocean. Whether this frontier will ever fully be tamed remains to be seen.

65 On 27 August 2019 the United States became the fourth party to ratify the Agreement, after Canada, Russia and the European Union. The Agreement will come into force upon ratification by all ten signatories. See US Department of State, 'The United States Ratifies Central Arctic Ocean Fisheries Agreement' Media Note (27 August 2019), https://translations.state. gov/2019/o8/27/the-united-states-ratifies-central-arctic-ocean-fisheries-agreement/. 